Tripartite feasibility assessment in developing a city college of Santa Rosa, Laguna: Basis for educational infrastructure development plan

Rodriguez, Ervie M.

Laguna College of Business and Arts, Philippines (yr8vz@yahoo.com; yr8vzrodriguez@gmail.com)

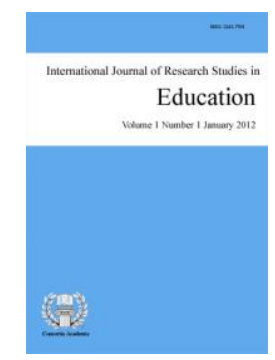

ISSN: $2243-7703$ Online ISSN: 2243-7711

OPEN ACCESS

\title{
Abstract
}

The main thrust of this study was to identify the feasibility of developing a City College of Santa Rosa in terms of Market, Technical, Financial, and Management Aspects; and to identify the level of its benefits in developing a City College in Santa Rosa in terms of Human Resource, Social, Economic, and Community Development. As an output, an Educational Infrastructure Development Plan was proposed to the City Government of Santa Rosa for emulation. This study used descriptive-correlational method. Three groups of respondents are the 1,607 Grade-12 SHS Students, 110 Human Resource Practitioners, and 155 Selected Local Government Employees. Through simple random sampling, the participants chosen from each group were the 217 SHS Students, 15 Human Resource Practitioners, and 20 Local Government Employees. A validated researcher-made survey instrument was used for data gathering. The statistical treatment used was Weighted Mean interpreted using the four-point Likert Scale, ANOVA, Pearson Product Moment Correlation, and Multiple Linear Regression. The findings revealed in developing a local college in terms of Market, Technical, Financial, and Management Aspects were all Highly Feasible. As assessed by the three groups, there was no significant difference in terms of Market and Financial Aspects, while there was a significant difference in terms of Technical and Management Aspects. However, on the level of benefit in developing a local college in terms of Human Resource, Social, Economic, and Community Development were all Highly Beneficial. Meanwhile, the significant relationship between the feasibility aspects and the development benefits was directly proportional.

Keywords: feasibility aspects; development benefits; city college; public infrastructure; educational infrastructure development plan 


\section{Tripartite feasibility assessment in developing a city college of Santa Rosa, Laguna: Basis for educational infrastructure development plan}

\section{Introduction}

Education is the fundamental link to nation-building. It plays an important role in liberating the people from poverty; thus, making it the greatest equalizer between the rich and the poor. Education enables citizens to fully utilize their full capacities to contribute most effectively to the country's progress that comprises the basic sectors for national development. Despite of all the programs, laws and provisions established to further improve the status of the Philippine Education System, Out-of-School Youths are still a prevalent dilemma due to lack of school institutions available from primary and especially to tertiary level (DepEd-EBEIS, 2008-2015).

Likewise, the City of Santa Rosa also has a dilemma with the scarcity of school institutions offering tertiary education. Currently, there are only six (6) private and one (1) public tertiary schools (SRL-SEPP, 2018). In this premise, the researcher intends to conduct a feasibility assessment in establishing a city college in Santa Rosa Laguna in terms of Market Aspect, Technical Aspect, Financial Aspect, and Management Aspect. Furthermore, the researcher intends to find out the benefits in developing a city college in Santa Rosa Laguna in terms of Human Resource Development, Social Development, Economic Development, and Community Development, with a goal of proposing an Educational Infrastructure Development Plan for Local Government Units (LGUs).

\subsection{Theoretical framework}

This study is anchored in the Feasibility Study Design Method (FSDM), a systematic process in developing feasibility studies or assessments which was conceptualized by Marcella Claase in 2012. The FSDM is vital in the process of performing feasibility studies to be more structured, thereby potentially optimizing its outcome. Relevant to the level of benefit in developing a City College in Santa Rosa Laguna, this study is likewise supported by the theory authored by Pierre-Richard Agenor in 2010 entitled "A Theory of Infrastructure-led Development" wherein the author believes on the country's development based on public infrastructure as the engine of growth.

\subsection{Conceptual framework (Research paradigm)}

\begin{tabular}{|c|c|}
\hline Independent Variables (IV) & $\begin{array}{c}\text { Dependent Variables (DV) } \\
\text { 1. The Aspects of Feasibility Assessment } \\
\text { in Developing the City College of Santa } \\
\text { Rosa Laguna in terms of; }\end{array}$ \\
1.1 Market Aspect & $\begin{array}{r}\text { 3. The Development Benefits in } \\
\text { 1.2 Technical Aspect } \\
\text { 1.3 Financial Aspect } \\
\text { 1.4 Management Aspect }\end{array}$ \\
Laghing a City College of Santa Rosa \\
Laguna terms of; \\
3.1 Human Resource Development \\
3.2 Social Development \\
3.3 Economic Development \\
3.4 Community Development
\end{tabular}

Figure 1. The paradigm of the study.

Figure 1 illustrates the Aspects of Feasibility Assessment in Developing the City College of Santa Rosa Laguna in terms of Market, Technical, Financial, and Management Aspects; and the Development Benefits in Establishing a City College in Santa Rosa Laguna in terms of Human Resource, Social, Economic, and Community Development. The results of the study undertaken become the basis for the "Proposed Educational Infrastructure Development Plan for the City Government of Santa Rosa Laguna”. 


\subsection{Statement of the problem}

The proposed study seeks to establish a viable Infrastructure Development Program for Education beneficial to the City of Santa Rosa Laguna and to its Stakeholders as a Community. The research also further seeks to answer the following questions:

1. How feasible is the development of the City College of Santa Rosa Laguna as assessed by the three (3) groups of respondents namely, the Grade-12 SHS Students, the Human Resource Practitioners, and the selected Local Government Employees in terms of the following: 1.1 Market Aspect, 1.2 Technical Aspect,1.3 Financial Aspect, and 1.4 Management Aspect

2. Is there a significant difference in the assessment of the three (3) groups of respondents in the feasibility of developing a City College in Santa Rosa Laguna along with the above-mentioned aspects of feasibility assessment?

3. What is the level of benefit in developing a City College in Santa Rosa Laguna in terms of: 3.1 Human Resource Development, 3.2 Social Development, 3.3 Economic Development, and 3.4 Community Development?

4. Is there a significant relationship between the feasibility of developing a City College in Santa Rosa Laguna, and the Level of its Development Benefits to the City of Santa Rosa Laguna?

5. Does the feasibility of developing a City College singly or in combination significantly impact the level of its development benefits to the City of Santa Rosa Laguna?

6. Based on the result of the study, what Infrastructure Development Plan may be proposed to the City Government of Santa Rosa Laguna?

\section{Hypotheses}

Ho 1: There is no significant difference in the assessment of the three (3) groups of respondents in the feasibility of developing a City College in Santa Rosa Laguna.

Ho 2: There is no significant relationship between the feasibility of developing a City College in Santa Rosa Laguna, and the level of its development benefits to the City of Santa Rosa Laguna such as human resource development, social development, economic development, and community development.

Ho 3: Feasibility of developing a City College does not significantly impact the level of its development benefits to the City of Santa Rosa Laguna.

\subsection{Scope and delimitations}

This study focused on the Feasibility Assessment in developing a City College of Santa Rosa Laguna. It provided the basis for an Educational Infrastructure Development Plan intended for the LGUs nationwide. Since there were numerous types of Feasibility Design Model, this study was constrained only to the aspects of feasibility study such as the market, technical, financial, and management. There were various benefits in developing a city college, this study was only limited in the development benefits in terms of human resource, social, economic, and community.

On the other hand, the targeted three (3) groups of respondents were the 1,607 Grade-12 SHS Students, the 110 Human Resource Practitioners, and the 155 Selected Local Government Employees. The participants were chosen through simple random sampling. A validated researcher-made survey instrument was used for data gathering. Meanwhile, this research study was one of the first created in the country; therefore, the resources were limited too. Indeed, the intention of the study covered only the City of Santa Rosa because the target 
respondents were all locators and stakeholders of the City. Thus, data were gathered through Surveys or Questionnaires, Interviews, and finally through Analysis and Interpretation conducted by the researcher during the semester of AY 2020-2021.

\section{Review of related literature and studies}

The repertoire of foreign and local literature included in the on-going study has contributed to the investigation of the topic on which the thesis is anchored. The study dealt with the development of a City College in Santa Rosa Laguna, it is important first to understand the concept of Feasibility Assessment or Study, and its underlying aspects. For the first aspect of feasibility known as the Market Aspects, authors Argosino (2015) and Camarillo (2015) defined it as the lifeblood of all feasibility studies. Second, the Technical Aspects are defined by Argosino (2015) and (Wolfe (2019) as the widest facet of feasibility study pertaining to the technical study on how the proposed endeavor will be realized. Third, the Financial Aspects were considered by authors Argosino (2015) and Wolfe (2019) as very important, recognizing the concept of "no funding, no project" basis. Fourth but not the least is the Management or Organizational Aspects as defined by authors Wolfe (2019) and Gregory (2019), pertaining to the business organization that is best suited for the project.

Meanwhile, to understand the benefits of developing local colleges, first on the list is the Human Resource Development as defined by authors Sharma (2015), Maurer-Klein (2019), and Montague, et. al. (2016), referring to the development of skills, capabilities, talents, aptitudes, proficiencies, and competencies through education, training, practice, and exposure to relevant experiences to further improve one's performance or ability. Second, Social Development as defined by authors Midgley et al. (2017) and Ahmadi (2017); as well as the associated descriptions illustrated from The New Brunswick Economic and Inclusion Plan (2019), World Bank Report (2019), and University of the People (2017), refers to the cultivation of well-being of the people in a society for them to achieve their full capacities. Third, the Economic Development as defined by authors Giugale (2015), Werner (2018), Mises (2018), Nko (2017), and Ahmadi (2017), refers to the process by which the economic well-being, standard of living, and quality of life of a nation, region, or local community were improved through collaborative efforts, in accordance with targeted goals and objectives. Fourth but not the least is that Community Development as described by authors Straza (2018), Eversley (2019), Odimayo (2018), and Zdenek and Walsh (2017), refers to empowering individuals and groups of people with the knowledge, talents, and skills they need to effect positive change within their communities.

Therefore, in considering the notable contributions of the authors mentioned, and the salient points taken from the publications illustrated as well, it is then concluded that it is high time for the City of Santa Rosa Laguna to establish its own local college institution. Any improvements administered in the feasibility aspects will bring boundless development benefits to the City and country as well. The contributions of the authors mentioned are vital in this study since this was not yet explored by earlier or any research undertakings at present.

\section{Methodology}

\subsection{Research design}

The method of research used by the proponent is of Descriptive-Correlational type to obtain the needed information. The researcher used descriptive because according to Keating (2005), the objective of the descriptive method is to determine if the data meets the parametric assumptions of normality. On the other hand, McCombes (2019), stated that a correlational research design measures a relationship between two (2) or more variables without the researcher controlling it. It aims to find out whether the variables change in the same or positive correlation, the variables change in the opposite or negative correlation, and lastly, if the variables have no relationship at all. Also, according to Bevans (2020), the Analysis of Variance or ANOVA is a statistical test used to analyze the difference between the means of more than two (2) groups. In this research, a One-way 
ANOVA set at 0.05 alpha levels was utilized as inferential statistics. Likewise, the research design attempted to identify the difference in the assessment of the three (3) groups of respondents.

\subsection{Research instrument}

The research instrument was a researcher-made survey questionnaire. It was divided into five (5) parts such as the Profile of the Respondents, the Purpose of the Study in Developing a City College, the Descriptions of Feasibility Aspects and Development Benefits, the Groundbreaking Development Plan, and lastly the Questionnaire itself. The research instrument was validated by experts to be used in this study. After validation, Cronbach's alpha was then administered to a lesser sample size for the purpose of reliability test, before it is being administered to the target three (3) groups of respondents.

\subsection{Respondents/Participants of the study}

The three (3) groups of respondents were the 1,607 Grade-12 SHS Students, 110 Human Resource Practitioners, and 155 Selected Local Government Employees. The total sample size of 252 were acquired using the stratified random sampling from the total population size of 1,872. The 252 sample size were the sum of the 217 SHS Students, 15 HR Practitioners, and 20 Local Government Employees comprising the three (3) groups of respondents.

\subsection{Data gathering procedure}

Data gathered for the first type of respondents which were the selected Grade-12 SHS students required the request letter endorsed by the City Planning and Development Coordinator (CPDC), and approved by the Schools Division Superintendent of DepEd Santa Rosa Division Office. The approved letter-request was photocopied and disseminated to the School Principals of the target SHS institutions. For the second type of respondents which were the Human Resource (HR) Practitioners, the researcher sought the aid of the Business Processing and Licensing Office (BPLO) and acquired the lists of manufacturing industries in the City of Santa Rosa, as well as the companies' official electronic mail addresses. A letter-request endorsed by the CPDC was sent via e-mail to the manufacturing companies addressed to the Human Resource Department. Lastly, the data gathering for the third type of respondents involved the Local Government Employees (LGEs) in Santa Rosa Laguna. Again, a letter-request to conduct surveys through questionnaires was endorsed by the CPDC.

The questionnaires for the target SHS students and HR Practitioners were administered and retrieved on-line via Google Forms; while printed questionnaires were manually disseminated and retrieved from the offices of the LGEs. Upon retrieval of all the questionnaires, the researcher summarized and presented it in a table. The acquired data results were tallied, applied the appropriate statistical treatments, and carefully analyzed with the assistance of the LCBA Resident Statistician.

\subsection{Treatment of quantitative data}

For this study, the researcher considered the use of descriptive-correlational statistics. Data taken from the questionnaire were analyzed, interpreted and then presented in a table.

1. The mean and the four-point Likert scale were used to determine the feasibility development and the level of benefit in developing a City College in Santa Rosa Laguna.

2. The Analysis of Variance or "ANOVA" was used to identify the significant difference in the assessment of the three (3) groups of respondents.

3. To establish the significant relationship between the feasibility development and the level of benefit in developing a local college, the Pearson Product Moment Correlation was employed. 
Rodriguez, E. M.

4. The multiple-linear regression was employed to identify the impact of the feasibility in developing the local college to the level of benefit in developing a City College in Santa Rosa Laguna.

\section{Results and discussion}

After careful and thorough analysis of investigation, the following are the findings of the summarized study based on the gathered data:

\subsection{On the feasibility assessment in developing a city college of Santa Rosa Laguna}

\section{Table 1}

Likert scale for the aspects of feasibility study

\begin{tabular}{|c|c|c|}
\hline Scale & Range & Interpretation \\
\hline 4 & $3.26-4.00$ & Highly Feasible \\
\hline 3 & $2.51-3.25$ & Feasible \\
\hline 2 & $1.76-2.50$ & Moderately Feasible \\
\hline 1 & $1.00-1.75$ & Not Feasible \\
\hline
\end{tabular}

1.1 The assessment for Market Aspect is $\mathbf{3 . 6 5}$, interpreted as Highly Feasible

1.2 The assessment for Technical Aspect is 3.56, interpreted as Highly Feasible

1.3 The assessment for Financial Aspect is $\mathbf{3 . 5 5}$, interpreted as Highly Feasible

1.4 The assessment for Management Aspect is $\mathbf{3 . 5 9}$, interpreted as Highly Feasible

\subsection{On the test of significant difference in the feasibility assessment of developing a city college of Santa Rosa}

Laguna along with the mentioned feasibility aspects

The probability values of market and financial aspects are $\mathbf{. 2 2 2}$ and $\mathbf{. 0 6 0}$, respectively which are both greater than the level of significance pegged at $\mathbf{. 0 5}$; thus, accepting the null hypothesis. Meaning, there is no significant difference as assessed by the three (3) groups of respondents. However, the probability values of technical and management aspects are $\mathbf{. 0 0 4}$ and $\mathbf{. 0 2 0}$, respectively which are both less than the level of significance fixed at $\mathbf{. 0 5}$; thus rejecting the null hypothesis. Meaning, there is a significant difference as assessed by the three (3) groups of respondents.

Table 2

Test of difference of the three (3) groups of respondents in the feasibility assessment

\begin{tabular}{|c|c|c|c|c|c|c|c|c|}
\hline \multicolumn{2}{|c|}{ Indicators } & SS & $\mathrm{df}$ & MS & $\mathrm{F}$ & Sig. & Decision & Remarks \\
\hline Market Aspects & $\begin{array}{c}\text { Between } \\
\text { Groups } \\
\text { Within } \\
\text { Groups } \\
\text { Total }\end{array}$ & $\begin{array}{c}.484 \\
39.780 \\
40.264\end{array}$ & $\begin{array}{c}2 \\
249 \\
251\end{array}$ & $\begin{array}{l}.242 \\
.160\end{array}$ & 1.515 & .222 & $\begin{array}{l}\text { Accept } \\
\text { ho }\end{array}$ & $\begin{array}{c}\text { Not } \\
\text { Significant }\end{array}$ \\
\hline $\begin{array}{l}\text { Technical } \\
\text { Aspects }\end{array}$ & $\begin{array}{c}\text { Between } \\
\text { Groups } \\
\text { Within } \\
\text { Groups } \\
\text { Total } \\
\end{array}$ & $\begin{array}{r}1.738 \\
38.510 \\
40.248 \\
\end{array}$ & $\begin{array}{c}2 \\
249 \\
251 \\
\end{array}$ & $\begin{array}{l}.869 \\
.155\end{array}$ & 5.619 & .004 & $\begin{array}{l}\text { Reject } \\
\text { ho }\end{array}$ & Significant \\
\hline $\begin{array}{l}\text { Financial } \\
\text { Aspects }\end{array}$ & $\begin{array}{c}\text { Between } \\
\text { Groups } \\
\text { Within } \\
\text { Groups } \\
\text { Total } \\
\end{array}$ & $\begin{array}{r}1.175 \\
51.465 \\
52.641 \\
\end{array}$ & $\begin{array}{c}2 \\
249 \\
251 \\
\end{array}$ & $\begin{array}{l}.588 \\
.207\end{array}$ & 2.843 & .060 & $\begin{array}{c}\text { Accept } \\
\text { ho }\end{array}$ & $\begin{array}{c}\text { Not } \\
\text { Significant }\end{array}$ \\
\hline $\begin{array}{l}\text { Management } \\
\text { Aspects }\end{array}$ & $\begin{array}{c}\text { Between } \\
\text { Groups } \\
\text { Within } \\
\text { Groups } \\
\text { Total }\end{array}$ & $\begin{array}{r}1.465 \\
45.836 \\
47.301\end{array}$ & $\begin{array}{c}2 \\
249 \\
251\end{array}$ & $\begin{array}{l}.732 \\
.184\end{array}$ & 3.979 & .020 & $\begin{array}{l}\text { Reject } \\
\text { ho }\end{array}$ & Significant \\
\hline
\end{tabular}


2.1 In terms of Market Aspects, there is no significant difference in the assessment of the three (3) groups of respondents as unanimously perceived by the respondents.

2.2 In terms of Financial Aspects, there is no significant difference in the assessment of the three (3) groups of respondents as unanimously perceived by the respondents.

2.3 In terms of Technical Aspects, there is a significant difference in the assessment of the three (3) groups of respondents as viewed differently by the respondents.

2.4 In terms of Management Aspects, there is a significant difference in the assessment of the three (3) groups of respondents as viewed differently by the three (3) groups of respondents.

\subsection{On the level of benefit in developing a city college of Santa Rosa Laguna}

Table 3

Likert scale for the level of development benefits

\begin{tabular}{|c|c|c|}
\hline Scale & Range & Interpretation \\
\hline 4 & $3.26-4.00$ & Highly Beneficial \\
\hline 3 & $2.51-3.25$ & Beneficial \\
\hline 2 & $1.76-2.50$ & Moderately Beneficial \\
\hline 1 & $1.00-1.75$ & Not Beneficial \\
\hline
\end{tabular}

3.1 The assessment for Human Resource Development is 3.69, interpreted as Highly Beneficial.

3.2 The assessment for Social Development is 3.65, interpreted as Highly Beneficial.

3.3 The assessment for Economic Development is 3.59, interpreted as Highly Beneficial.

3.4 The assessment for Community Development is 3.66, interpreted as Highly Beneficial.

4.4 On the test of significant relationship between the feasibility assessment of developing a city college of

Santa Rosa Laguna, and the level of its development benefits to the city of Santa Rosa Laguna

All of the probability values are less than the level of significance fixed at $\mathbf{. 0 5}$; thus, rejecting the null hypothesis. The relationship between the Feasibility of Developing a City College, and the Level of its Development Benefits to the City of Santa Rosa Laguna is significantly proportional.

\section{Table 4}

Test of significant relationship between the feasibility of developing a city college of Santa Rosa Laguna, and the level of its development benefits to the City of Santa Rosa Laguna

\begin{tabular}{|c|c|c|c|c|c|c|}
\hline Feasibility Aspects & Development Benefits & $r$-value & $p$-value & Remarks & Decisi & \\
\hline \multirow{4}{*}{ Market Aspects } & Human Resource & $.622^{* *}$ & .000 & Significant & Reject & Ho \\
\hline & Social & $.624^{* *}$ & .000 & Significant & Reject & Ho \\
\hline & Economic & $.529^{* *}$ & .000 & Significant & Reject & Ho \\
\hline & Community & $.559^{* *}$ & .000 & Significant & Reject & Ho \\
\hline \multirow{4}{*}{ Technical Aspects } & Human Resource & $.648^{* *}$ & .000 & Significant & Reject & Ho \\
\hline & Social & $.608^{* *}$ & .000 & Significant & Reject & Ho \\
\hline & Economic & $.609^{* *}$ & .000 & Significant & Reject & Ho \\
\hline & Community & $.607^{* *}$ & .000 & Significant & Reject & Ho \\
\hline \multirow{4}{*}{ Financial Aspects } & Human Resource & $.641^{* *}$ & .000 & Significant & Reject & Ho \\
\hline & Social & $.620^{* *}$ & .000 & Significant & Reject & Ho \\
\hline & Economic & $.648^{* *}$ & .000 & Significant & Reject & Ho \\
\hline & Community & $.632^{* *}$ & .000 & Significant & Reject & Ho \\
\hline \multirow{4}{*}{ Management Aspects } & Human Resource & $.660^{* *}$ & .000 & Significant & Reject & Ho \\
\hline & Social & $.684^{* *}$ & .000 & Significant & Reject & Ho \\
\hline & Economic & $.653^{* *}$ & .000 & Significant & Reject & Ho \\
\hline & Community & $.704^{* *}$ & .000 & Significant & Reject & Ho \\
\hline
\end{tabular}


Rodriguez, E. M.

4.5 On the Impact of Feasibility Assessment in Developing a City College of Santa Rosa Laguna with its

Development Benefits to the City of Santa Rosa

5.1 All the four variables such as Market, Technical, Financial, and Management Aspects have a significant impact on the development benefits to the City of Santa Rosa Laguna. The probability values of .000, .048, .046 and $\mathbf{. 0 0 1}$ are less than the level of significance fixed at $\mathbf{. 0 5}$, thus rejecting the null hypothesis. The feasibility aspects have a significant impact with the human resource development benefits to the City of Santa Rosa by $53.3 \%$.

Table 5.1

Regression analysis on the impact of feasibility assessment of developing a city college and its development benefits to the city of Santa Rosa Laguna in terms of human resource development

\begin{tabular}{|c|c|c|c|c|c|c|c|}
\hline \multirow{2}{*}{ Model } & \multicolumn{2}{|c|}{$\begin{array}{l}\text { Unstandardized } \\
\text { Coefficients }\end{array}$} & \multirow{2}{*}{$\begin{array}{l}\text { Standardized } \\
\text { Coefficients } \\
\text { Beta }\end{array}$} & \multirow[t]{2}{*}{$\mathrm{T}$} & \multirow{2}{*}{ Sig. } & \multirow{2}{*}{ Remarks } & \multirow{2}{*}{ Decision } \\
\hline & $\mathrm{B}$ & Std. Error & & & & & \\
\hline (Constant) & 1.313 & .151 & & 8.695 & .000 & & \\
\hline Market Aspects & .221 & .052 & .261 & 4.218 & .000 & Significant & Reject ho \\
\hline Technical Aspects & .131 & .066 & .154 & 1.987 & .048 & Significant & Reject ho \\
\hline Financial Aspects & .117 & .059 & .158 & 2.001 & .046 & Significant & Reject ho \\
\hline $\begin{array}{c}\text { Management } \\
\text { Aspect }\end{array}$ & .202 & .062 & .257 & 3.234 & .001 & Significant & Reject ho \\
\hline
\end{tabular}

5.2 The Market and Management Aspects both have a probability value of $\mathbf{. 0 0 0 ,}$, which is less than the level of significance fixed at $\mathbf{. 0 5}$; thus rejecting the null hypothesis. Meanwhile, the Technical and Financial Aspects have a probability values of $\mathbf{. 8 0 7}$ and $\mathbf{. 2 8 3}$, respectively which are greater than the level of significance fixed at .05; thus accepting the null hypothesis. The two (2) variables namely, the market and management aspects have a significant impact with the social development benefits to the City of Santa Rosa by $\mathbf{5 3 . 8} \%$.

5.3 The Financial and Management Aspects have a probability values of .002 and .001, respectively which are less than the level of significance fixed at $\mathbf{. 0 5}$; thus rejecting the null hypothesis. Meanwhile, the Market and Technical Aspects have a probability values of .091 and .131, respectively which are greater than the level of significance fixed at .05; thus accepting the null hypothesis. The two (2) variables namely, the financial and management aspects have a combined significant impact with the economic development benefits to the City of Santa Rosa by $\mathbf{4 8 . 7} \%$.

\section{Table 5.2}

Regression analysis on the impact of feasibility assessment of developing a city college with its development benefits to the city of Santa Rosa Laguna in terms of social development

\begin{tabular}{|c|c|c|c|c|c|c|c|}
\hline \multirow[t]{2}{*}{ Model } & \multicolumn{2}{|c|}{$\begin{array}{l}\text { Unstandardized } \\
\text { Coefficients }\end{array}$} & \multirow{2}{*}{$\begin{array}{c}\text { Standardized } \\
\text { Coefficients } \\
\text { Beta }\end{array}$} & \multirow[t]{2}{*}{$\mathrm{T}$} & \multirow[t]{2}{*}{ Sig. } & \multirow[t]{2}{*}{ Remarks } & \multirow[t]{2}{*}{ Decision } \\
\hline & B & Std. Error & & & & & \\
\hline (Constant) & 1.409 & .146 & & 9.668 & .000 & & \\
\hline Market Aspects & .251 & .051 & .304 & 4.948 & .000 & Significant & Reject ho \\
\hline Technical Aspects & .016 & .064 & .019 & .244 & .807 & $\begin{array}{c}\text { Not } \\
\text { Significant }\end{array}$ & Accept ho \\
\hline Financial Aspects & .061 & .057 & .085 & 1.076 & .283 & $\begin{array}{c}\text { Not } \\
\text { Significant }\end{array}$ & Accept ho \\
\hline $\begin{array}{c}\text { Management } \\
\text { Aspects }\end{array}$ & .316 & .060 & .416 & 5.251 & .000 & Significant & Reject ho \\
\hline
\end{tabular}


Tripartite feasibility assessment in developing a city college of Santa Rosa, Laguna

\section{Table 5.3}

Regression analysis on the impact of feasibility assessment of developing a city college with its development benefits to the city of Santa Rosa Laguna in terms of economic development

\begin{tabular}{|c|c|c|c|c|c|c|c|}
\hline \multirow[t]{2}{*}{ Model } & \multicolumn{2}{|c|}{$\begin{array}{l}\text { Unstandardized } \\
\text { Coefficients }\end{array}$} & \multirow{2}{*}{$\begin{array}{c}\text { Standardized } \\
\text { Coefficients } \\
\text { Beta }\end{array}$} & \multirow[t]{2}{*}{$\mathrm{T}$} & \multirow[t]{2}{*}{ Sig. } & \multirow[t]{2}{*}{ Remarks } & \multirow[t]{2}{*}{ Decision } \\
\hline & B & Std. Error & & & & & \\
\hline (Constant) & 1.216 & .177 & & 6.860 & .000 & & \\
\hline Market Aspects & .105 & .062 & .110 & 1.697 & .091 & Not Significant & Accept ho \\
\hline $\begin{array}{l}\text { Technical } \\
\text { Aspects }\end{array}$ & .117 & .077 & .123 & 1.514 & .131 & Not Significant & Accept ho \\
\hline Financial Aspects & .216 & .069 & .260 & 3.131 & .002 & Significant & Reject ho \\
\hline $\begin{array}{c}\text { Management } \\
\text { Aspects }\end{array}$ & .249 & .073 & .284 & 3.405 & .001 & Significant & Reject ho \\
\hline
\end{tabular}

Notes. $\mathrm{R}-$ Square $=.487, \mathrm{~F}$-value $=58.609$, Adjusted R Square $=.479$, and Significance $=.000$.

5.4 The Market and Management Aspects have a probability values of $\mathbf{. 0 0 9}$ and $\mathbf{. 0 0 0}$, respectively which are less than the level of significance fixed at $\mathbf{. 0 5}$; thus rejecting the null hypothesis. Meanwhile, Technical and Financial Aspects have a probability values of $\mathbf{. 5 4 4}$ and $\mathbf{. 1 6 0}$, respectively which are greater than the level of significance fixed at $\mathbf{. 0 5}$; thus accepting the null hypothesis. The two (2) variables namely, the market and management aspects have a combined significant impact with the community development benefits to the City of Santa Rosa by $\mathbf{5 2 . 7} \%$.

\section{Table 5.4}

Regression analysis on the impact of feasibility assessment of developing a city college with its development benefits to the city of Santa Rosa Laguna in terms of community development

\begin{tabular}{|c|c|c|c|c|c|c|c|}
\hline \multirow[t]{2}{*}{ Model } & \multicolumn{2}{|c|}{$\begin{array}{l}\text { Unstandardized } \\
\text { Coefficients }\end{array}$} & \multirow{2}{*}{$\begin{array}{c}\text { Standardized } \\
\text { Coefficients } \\
\text { Beta }\end{array}$} & \multirow[t]{2}{*}{$\mathrm{T}$} & \multirow[t]{2}{*}{ Sig. } & \multirow[t]{2}{*}{ Remarks } & \multirow[t]{2}{*}{ Decision } \\
\hline & $\mathrm{B}$ & Std. Error & & & & & \\
\hline (Constant) & 1.381 & .155 & & 8.890 & .000 & & \\
\hline Market Aspects & .143 & .054 & .165 & 2.652 & .009 & Significant & Reject ho \\
\hline $\begin{array}{l}\text { Technical } \\
\text { Aspects }\end{array}$ & .041 & .068 & .047 & .608 & .544 & Not Significant & Accept ho \\
\hline Financial Aspects & .085 & .060 & .112 & 1.409 & .160 & Not Significant & Accept ho \\
\hline $\begin{array}{l}\text { Management } \\
\text { Aspects }\end{array}$ & .382 & .064 & .477 & 5.952 & .000 & Significant & Reject ho \\
\hline
\end{tabular}

Notes. $\mathrm{R}-$ Square $=.527, \mathrm{~F}$-value $=68.875$, Adjusted $\mathrm{R}$ Square $=.520$, and Significance $=.000$.

4.6 Proposed educational infrastructure development plan to the local government unit of Santa Rosa Laguna.

As an output, a draft "Proposed Educational Infrastructure Development Plan" will be presented to the City Government of Santa Rosa Laguna for review and approval. The Feasibility Aspects that were assessed in this study will be included in the said plan, along with the Development Benefits. The proposed plan is subjected for improvements, with the aid of a Powerhouse Committee.

\section{Conclusion/Reflections and directions for future use}

\subsection{Conclusions}

The following conclusions are hereby derived on the basis of the aforementioned findings in the development of City College of Santa Rosa Laguna:

1. That the general assessment of Highly Feasible in the feasibility aspects of developing a City College of Santa Rosa as assessed by the three (3) groups of respondents indicates the following: 
1.1 For Market Aspect, highly feasible indicates that higher education is of great demand to the marginalized citizenry as a means to level-up their Standard-of-Living.

1.2 For Technical Aspect, highly feasible indicates that the City Engineering Office has all the technical expertise and capabilities to develop a school with strong foundation in a strategic location.

1.3 For Financial Aspect, highly feasible indicates that the City has 110 manufacturing companies that may be tapped to invest on scholarship grants in exchange for graduate professionals.

1.4 For Management Aspect, highly feasible indicates that the City Government can easily organize a Committee which is vital in managing the school operations and for providing trainings.

2. That the three (3) groups of respondents may either have a similar or different perception in the assessment of developing a City College of Santa Rosa Laguna, depending on the following:

For Market Aspect, there is no significant difference in the assessment of the respondents. The local college development will be a viable means to satisfy the demand for higher education.

For Financial Aspect, there is no significant difference in the assessment of respondents. Budgetary is very important and will always be needed in all the stages of local college development.

For Technical Aspect, there is a significant difference in the assessment of the respondents. It is vital to consider first the needs and preferences of the beneficiaries for integration.

For Management Aspect, there is a significant difference in the assessment of the respondents. Knowing the organizational structure is vital in putting the right person for the right tasks.

3. That the general assessment in the level of benefit in developing a City College in Santa Rosa Laguna is Highly Beneficial in terms of development benefits indicate the following:

3.1 For Human Resource Development, highly beneficial indicates that the enhancement of knowledge and skills of the students are beneficial towards professionalism.

3.2 For Social Development, highly beneficial indicates that Education is truly the greatest equalizer, thereby closing the gap between the rich and the poor.

3.3 For Economic Development, highly beneficial indicates that the quality of life of the people is directly proportional to economic growth.

3.4 For Community Development, highly beneficial indicates that being a responsible citizen is contributory in maintaining peace and order in the community.

4. That there is a Significant Relationship between the Feasibility of Developing a City College, and the Level of its Benefit to the City of Santa Rosa Laguna. It indicates that the Feasibility Aspects were all directly proportional to the Development Benefits it will bring to the City. Therefore, establishing a local college with great considerations to its feasibility aspects such as Market, Technical, Financial, and Management will bring great development benefits as well to the City of Santa Rosa in terms of Human Resource, Social, Economic, and Community Development.

5. That the Feasibility of Developing a City College has a Combination Significant Impact with the Level of its Development Benefits to the City of Santa Rosa Laguna:

5.1 For the Feasibility Aspects, all have a Significant Impact with the Human Resource Development benefits. It indicates that any positive interventions to human resource development has a significant impact caused by the market, technical, financial, and management aspects. 
5.2 For the Feasibility Aspects of Market and Management, both have a Significant Impact with the Social Development benefits. It indicates that any positive interventions to social development has a significant impact caused by the Market and Management Aspects

5.3 For the Feasibility Aspects of Financial and Management, both have a Significant Impact with the Economic Development benefits. It indicates that any positive interventions to economic development has a significant impact caused by the financial and management aspects.

5.4 For the Feasibility Aspects of Market and Management, both have a Significant Impact with the Community Development benefits. It indicates that any positive interventions to community development has a significant impact caused by the market and management aspects.

6. That an "Educational Infrastructure Development Plan" may be proposed in the successful establishment of a local college, along with its feasibility aspects and development benefits it will bring to the City of Santa Rosa. The said plan will also be recommended to other LGUs without a local college in the country. This is a viable means of sharing a best practice worthy of emulation.

\subsection{Directions for future use}

Based on the findings and conclusions, the following recommendations are hereby provided:

1. Based on the Aspects of Feasibility, the general assessment in developing a City College of Santa Rosa Laguna is Highly Feasible. Hence, the following are recommended:

1.1 For Market Aspect, the high demand for higher education must be addressed accordingly in order to resolve a social problem, and eventually be flipped into an economic opportunity.

1.2 For Technical Aspect, the decision-makers in developing a local college must assign the City Engineering Office to spearhead the building construction and facilities maintenance.

1.3 For Financial Aspect, the City still has other options for funding resources. The City may still acquire budget from the national government or tap the private sectors for scholarship grants.

1.4 For Management Aspect, the creation of a Powerhouse Committee is vital in developing the school building, and eventually in managing the school operations.

2. The three (3) groups of respondents may have similar and different perception in developing a City College of Santa Rosa Laguna, but entails suitable recommendations for the following:

For Market Aspect, although establishing the City College may satisfy the demand, the qualifications in accepting the students must be standardized, prioritizing the marginalized citizens.

For Financial Aspect, the City for cost savings may acquire budget from the national government or may tap the companies for scholarship grants in exchange of graduate professionals.

For Technical Aspect, the decision-makers must consider first the needs and preferences of the beneficiaries to be integrated in developing the local college.

For Management Aspect, understanding the Organizational Structure will allow the decision-makers to identify the people involved, assess them, then select the right people to do the job required.

3. Based on the Level of Benefits, developing a City College of Santa Rosa Laguna is Highly Beneficial. Hence, the following are recommended:

3.1 For Human Resource Development, the Curriculum Development must be handled with great 
importance because honing the knowledge, intellect, decision-making, and other necessary skills rely on the comprehensiveness of the curriculum. The academic committee must handle this.

3.2 For Social Development, Out-of-School Youth and School Drop-outs due to poverty must be eliminated by prioritizing them as beneficiaries for higher education. This will sustain the well-being of the youth sector, giving them hope in closing the gap between the rich and the poor.

3.3 For Economic Development, Cohort Survival rate of the college graduate must be well-monitored and must be maintained at a high level. The higher the level of education leads to the higher chances of landing on a high-paying job, and resulting to higher income generation from taxes.

3.4 Community Development, the Youth Sector must be empowered to join in various community activities. Industry locators may also contribute in this noble endeavor by grooming the youth in various sponsored Corporate Social Responsibility (CSR) or Philanthropical Activities.

4. The feasibility aspects of developing a local college have a Significant Relationship with the development benefits to the City of Santa Rosa Laguna. Indeed, the development of both factors is considered directly proportional. Thus, the improvements introduced in the feasibility aspects will bring better development benefits to the City of Santa Rosa Laguna.

To improve the Market Aspect, the courses offered should be in numerous varieties to satisfy the high demand for higher education; thereby producing competent and highly skilled professionals.

To improve the Technical Aspect, the City must have consistent exposures and hands-on experiences on technological breakthroughs, in order to adapt with the latest global trends.

To improve the Financial Aspect, proper tax collection in the City must be observed accordingly. The City may also venture in various economic enterprises to increase income generation.

To improve the Management Aspect, a Committee composed of powerhouse members is necessary to oversee and manage the operations in developing a local college.

5. Developing a City College has a Combination Significant Impact with its Development Benefits to the City of Santa Rosa Laguna as stated:

5.1 To create a significant impact to Human Resource Development, satisfying the demand for college graduate professionals must be implemented for Market Aspect; while a State-of-the-Art college institution that is conducive for learning will suffice the Technical Aspect. Likewise, budget allocation of the local government for the well-being of the students will answer for the Financial Aspect; while filling the Organizational Structure with needed jobs will serve the Management Aspect.

5.2. To create a significant impact to Social Development, satisfying the demand for Education as a societal service to the citizens will serve the Market Aspect; while youth empowerment in various societal engagement activities will suffice the Management Aspect.

5.3 To create a significant impact to Economic Development, even though a local college is a public service, investment returns must be expected to suit the Financial Aspect; while accumulation of sponsors for scholarship grants in exchange for graduate professionals will serve Management Aspect.

5.4 To create a significant impact to Community Development, promotion of Environment Sustainability is suited for Market Aspect; while to encourage participation of the citizens in various civil society organizations towards a common goal will suffice the Management Aspect as well.

6. To create the "Educational Infrastructure Development Plan" will require all the help of the local agencies, private sectors, academies, and civil societies, and group themselves to committees that are needed to be 
established. Various factors must all be considered in order to integrate all the contributed concepts into one holistic masterplan. The said plan will serve as a guide in the successful establishment of a local college; considering its feasibility aspects and development benefits to the City of Santa Rosa Laguna. The said plan may also be shared to interested LGUs for emulation.

7. For the future researchers, to update and add other applicable feasibility aspects, development benefits, concepts, basis, related literature, survey tools, statistical treatments, and others to further improve the study, serve its purpose, and prolong its usage to stand the test of time.

Currently, there are very few studies available when it comes to developing school institutions. With that, it is recommended that more studies like this should be made by the future researchers to ensure more local colleges will be developed nationwide. The more studies will be made in developing higher education institutions, the more benefit it will bring in establishing local colleges in the country.

\section{References}

Agenor, P. R. (2006). A theory of infrastructure-led development. Centre for Growth and Business Cycle Research Discussion Paper Series 83, Economics. The University of Manchester.

Ahmadi, M. (2017). Higher education and national development. daily outlook Afghanistan. Retrieved from http://www.outlookafghanistan.net/topics.php?post_id=19291

Al-Khamis F. A. (2018). The mediating role of employee job performance in the impact of open book management dimensions on customer satisfaction. Business: Theory and Practice. Retrieved from https://journals.vgtu.lt/index.php/BTP/article/view/8087

Benefits of education are societal and personal. University of the People. Retrieved from https://www.uopeople.edu/blog/benefits-of-education-are-societal-and-personal/

Bevans, R. (2020). An introduction to the one-way ANOVA. Scribbr. Retrieved from https://www.scribbr.com/statistics/one-way-anova/

Camarillo, J. (2019). Marketing aspects of feasibility study. SlideShare. Retrieved from https://www.slideshare.net/jezielcamarillo/marketing-aspects-of-feasibility-study

Claase, M. (2012). Optimizing feasibility studies: Base on a grounded theory type comparison of feasibility design research (pp. 1-15).

Eversley, J. (2019). Social and community development: An introduction. Macmillan.

Giugale, M. (2015). Economic development. What everyone needs to know. Oxford University Press.

Learner information system and enhanced basic education information system updating for beginning of school year 2015-2016. Department of Education, DO 26, S. 2015. Republic of the Philippines. Retrieved from https://www.deped.gov.ph/2015/06/26/do-26-s-2015-learner-information-system-lis-and-enhanced-basi c-education-information-system-ebeis-updating-for-beginning-of-school-year-bosy-2015-2016/

Maurer-Klein, H. (2019). Viewpoint: The changing role of HR. Organizational and Employee Development, SHRM-SCP. HR/Advantage Advisory, Pittsburgh.

Midgley, J., \& Conley, A. (2010). Social work and social development: Theories and skills for developmental social work. Oxford Scholarship Online. https://doi.org/10.1093/acprof:oso/9780199732326.001.0001

Mises, L. V. (2018). The definition of economic progress. Mises Institute. Excerpted from Chapter 16 of Theory and History in 1957. Retrieved from https://mises.org/library/definition-economic-progress

Montague, A., Larkin, R., \& Burgess, J. (2016). Asia Pacific human resource management and organizational effectiveness, impacts on practice.

Nye, N., \& Schramm, R. (1999). Community development and CDCs. Seedco Handbook.

Overcoming Poverty Together. (2014). Economic and social inclusion corporation. The New Brunswick Economic and Social Inclusion Plan 2014-2019. National Collaborating Centre for Determinants of Health.

Policy Guidelines on Classroom Assessment for the K to 12 Basic Education Program. Department of Education, DO 8, s. 2015. Republic of the Philippines. Retrieved from 
https://www.deped.gov.ph/2015/04/01/do-8-s-2015-policy-guidelines-on-classroom-assessment-for-thek-to-12-basic-education-program/

Republic Act (RA) No. 10533 also known as the "Enhanced Basic Education Act of 2013". Implementing Rules and Regulation. Department of Education, Republic of the Philippines. Retrieved from https://www.deped.gov.ph/2013/09/24/do-43-s-2013-implementing-rules-and-regulations-irr-of-republic -act-no-10533-otherwise-known-as-the-enhanced-basic-education-act-of-2013/276/

Republic Act No. 10931 also known as the "Universal Access to Quality Tertiary Education Act of 2016". First regular Session, $17^{\text {th }}$ Congress. Congress of the Philippines, Metro Manila, Republic of the Philippines. Retrieved from http://legacy.senate.gov.ph/republic_acts/ra\%2010931.pdf

Republic Act No. 7722 also known as the "Higher Education Act of 1994". Commission on Higher Education, Republic of the Philippines. Retrieved from https://chedro3.page.t1/Background.htm

Republic Act No. 7796 also known as the "Technical Education and Skills Development Act of 1994". Technical Education Skills and Development Authority, Republic of the Philippines. ChanRobles Publishing Company. Retrieved from https://www.tesda.gov.ph/uploads/File/REPUBLIC\%20ACT\%20NO.\%207796.pdf

Republic Act No. 8292 also known as the "Higher Education Modernization Act of 1997". Commission on Higher Education, Republic of the Philippines. Retrieved from https://ched.gov.ph/wp-content/uploads/2017/05/Republic-Act-No.-8292-The-Higher-Education-Moder nization-Act-of-1997.pdf

Robinson J. W. Jr., \& Green, G. P. (2010). Introduction to community development: Theory, practice, and service-learning. SAGE Publications.

Sahoo, Dash, R. K., \& Nataraj, G. (2010). Infrastructure development and economic growth in China. Institute of Developing Economies. IDE Discussion Paper No. 261, pp. 1-40.

Sharma, K. K. (2015). Human resources: Its classification and categorization. Department of Labour and Social Welfare.

Social Sustainability and Inclusion. (2020). Understanding poverty. The World Bank. Retrieved from https://www.worldbank.org/en/topic/socialsustainability/overview

Socio-Economic and Physical Profile. (2018). City planning and development office. City Government of Santa Rosa, Laguna.

Straza, M. (2020). Community development: What it is, its importance, and how to contribute in your city. Straza Consulting. Retrieved from https://consultstraza.com/community-development-what-it-is-its-importance-and-how-to-contribute-inyour-city/

Technical Aspect. (2019). Idocpub. Retrieved from https://idoc.pub/documents/technical-aspect-k6nqd0wd394w The 17 Sustainable Development Goals. (2015). Department of Economic and Social Affairs. Sustainable Development. United Nations. Retrieved from https://sdgs.un.org/goals

The 1987 Constitution of the Republic of the Philippines. Retrieved from http://hrlibrary.umn.edu/research/Philippines/PHILIPPINE\%20CONSTITUTION.pdf

The World Bank Annual Report. (2019). Ending poverty, investing on opportunity. The World Bank. Retrieved from https://openknowledge.worldbank.org/handle/10986/32333

Venkajah Naidu, S. M. (2017). Education is a key instrument in developing social infrastructure. Press Information Bureau.

What is community development? Scottish Community Development Center. Scotland 361532 and Scottish Charity SC040614. Retrieved from https://www.scdc.org.uk/who/what-is-community-development

What is Social Development? (2008). Economic and social inclusion corporation. New Nouveau Brunswick Canada. Overview and Background 2008-2009. Retrieved from https://www2.gnb.ca/content/gnb/en/departments/esic/overview/content/what_is_social_development.ht $\underline{\mathrm{ml}}$

Wolfe, L. (2019). How to write a feasibility study step by step? The Balance Small Business. Retrieved from https://www.thebalancecareers.com/what-is-a-feasibility-study-3514853

158 Consortia Academia Publishing (A partner of Network of Professional Researchers and Educators) 
Tripartite feasibility assessment in developing a city college of Santa Rosa, Laguna

Zdenek, R. O., \& Walsh, D. (2017). Navigating community development, harnessing comparative advantages to create strategic partnerships. Springer. https://doi.org/10.1057/978-1-137-47701-9_6 
Rodriguez, E. M.

160 Consortia Academia Publishing (A partner of Network of Professional Researchers and Educators) 